\title{
Seigniorage Revenue and Inflation Tax: Testing Optimal Seigniorage Theory for Turkish Economy
}

\author{
Bulent Doğru ${ }^{1}$ \\ ${ }^{1}$ Faculty of Economic and Administrative Science, Gumushane University, Gumushane, Turkey \\ Correspondence: Bulent Doğru, Faculty of Economic and Administrative Science, Gumushane University, \\ Gumushane, Turkey. E-mail: buldogru@gumushane.edu.tr
}

Received: April 15, 2013

Accepted: April 30, 2013

Online Published: May 21, 2013

doi:10.5539/ijef.v5n6p122

URL: http://dx.doi.org/10.5539/ijef.v5n6p122

\begin{abstract}
The goal of this study is to test the implication of Mankiv's (1987) optimal seigniorage theory suggesting that in the long run higher tax rates are associated with higher inflation rates and higher nominal interest rates for Turkish Economy using time series dataset for the time period 1980-2011.We examine the long run relationship between nominal interest rates, inflation and tax revenue. For this purpose, we estimate the Mankiw'soptimal seigniorage model for Turkish Economy with the cointegration and vector error correction methods (VECM) techniques. According to econometric result, in long run there is a causality relationship from inflation and tax revenue to nominal interest rates. However, in short run we could not find any evidence that support the causality from inflation and tax revenue to nominal interest rates.
\end{abstract}

Keywords: seigniorage and inflation tax, optimal seigniorage theory, Turkish economy, error correction model, cointegration analysis

\section{Introduction}

There are two sources for governments to raise their revenues: The first source is the direct taxation put on output, and the second source is seigniorage. Seigniorage is also known as printing new money and defined as the value of real resources acquired by the government through its power of sovereignty on its monopoly of printing money (Begg, Fischer and Dornbusch, 1994). But, both sources of revenue cause deadweight social losses (Mankiw, 1987: 327-328), moreover inflation also brings some other social costs, such as reducing purchasing power of consumers, shoe leather costs, menu costs, variability in relative prices, imperfect indexation in the tax code and inconvenience. These costs are not very high for the moderate inflation commonly seen in industrial or developed countries (Foote, 2010: 58), but for developing countries, these costs can cause drastic social results.

We know that a developing country has fewer options to finance its increasing public sector deficits compared with developed countries. These countries can finance their deficits with three different ways: Borrowing from banking sector, both state-owned and commercial bank, including the central bank, from non-bank national alternatives and from the international financial markets.As the financial system, consisted of banking sector, non-bank financial institutions and the financial markets are poor and shallow in developing countries, the financing deficit by the way one is relatively limited. After liberalization of the financial markets by the 1980s, borrowing from the international financial markets has become the most common way of financing deficits for developing countries (Samimi et al., 2012: 82-83). But when these countries lose their credibility as a result of debt crises, governments were forced to borrow from the central bank and commercial banking system. This requirement has forcedcentral banksto printmoney. For a developing country, domestic borrowing possibilities, to a great extent, may increase inflation. In this case it is a question whether the governmentscould collect maximum seigniorage revenue thanks to its monopoly on printing money (Korap, 2006: 5).

On the other hand, inflation tax is also one of the drastic results of high inflation. Inflation tax is a term which refers to the reduction inthe real value of financial stocks in the hands ofthe peopledue to the effects of inflation. In other words, inflation tax has a welfare cost effect (Cooley and Hansen, 1989: 742). The real financial loss can be expressed as loss of purchasing power of money holder. Seignoirage revenue creates inflation and this inflation cause financial losses. There should be positive correlation between printing money, namely seigniorage revenue, and inflation tax. According to optimal seignoraige theory, nominal interest rates and inflation are determined due to government'snecessity to finance its budget deficit. If marginal cost of the tax is 
increasing with income, then a positive relationship will occur between inflation and nominal interest rates and taxes (Aslan, 2003: 125). The theory indicates that that nominal interest rates and inflation are individually random walks, but suggests that the nominal interest rates and inflation move together with tax rates.Mankiw tested this theory for the United States of America (USA) for the period 1952-1985, and provided some support for the theory (Mankiw, 1987: 327).

Many economists including Bailey (1956), Cagan (1956), Friedman (1971), Phelps (1973, 1972), Klein and Neumann (1990) and Marty (1967) analyze seigniorage revenue as a source of income to the government. In this point there are two different approaches trying to explain the relationship between seignoraige, nominal interest rates and inflation (Gürbüz et al, 2009: 55-56): The first approach belongs to monetarists. According to the monetarist theory an increase in the monetary base will increase monetary inflation. The rise in inflation reduces real money balances through a rising in the nominal interest rates. This affects the readjustment of cash between economic agents, and leads a rise in stocks and reduction of private consumption. According to the second approach developed by Phelps (1973), seigniorage revenue is equal to the multiplication of nominal interest rates and real money balances. Then, Phelps suggests that the income obtained by government depends on private sector's nominal interest rate's losses.

In this paper we investigate the relationship between real seigniorage revenue and inflation tax for Turkish economy in a long time period 1980-2012. According to vector error correction (VECM) result of the study inflation and tax revenue has long run causality on interest rates. In long run inflation and tax revenue increases nominal interest rates positively and significantly. But in short run there is not causality between variables.

The outline of the paper is as follows. Section two gives a brief introduction on Turkish economy, inflation tax and seigniorage revenue, while section three introduces Mankiw's (1987) optimal seignoriage model. Section four estimates the empiric model and inference of econometric findings. The final section concludes the study.

\section{Turkish Economy, Inflation Tax and Seigniorage Revenue}

Turkish economy lived a chronic high inflationary problem between 1978 and 2002. During this time period Turkish economy has experienced two digits and sometimes three digits inflationary years as in 1982 and 1994. In Table 1 inflation experience and narrow (M1) and broad money (M2) growth rate of Turkish economyis listed. While Table 2 shows inflation experience of some selected developing countries with narrow money M1 growth rate. From table 1, it is seen that Turkish experience was neither hyperinflation of the two digits price increases in a monthly time period nor a moderate inflation of the single digit in an annual time period; however Turkish experienceconstituted a privileged position in the world economy (Korap, 2006: 2). 2002 is the turning point in Turkish experience of inflation, because CBRT (Central Bank of the Republic of Turkey) changed its monetary policy strategy from exchange rate anchor and money targeting regimes to the explicitly inflation targeting regime. Namely, a tradeoff between intermediate targeting regimes was happened in 2002. After that a drastic decline in inflationary process of Turkish economy has seen, and annual inflation rate has begun to cycle between $5 \%$ and $10 \%$. It is also clear that there is a parallel movement between M2 growth rate and inflation rate, while M1 is not correlated with inflation at the same time period table 1.

Table 1. Money stock and inflation in Turkey (\% of GNP)

\begin{tabular}{llll}
\hline Time Period & $\boldsymbol{\pi}(\%)$ & M1/GNP $(\%)$ & M2/GNP (\%) \\
\hline $\mathbf{1 9 7 0 - 1 9 7 9}$ & 24,27 & 17,04 & 21,16 \\
$\mathbf{1 9 8 0 - 1 9 8 9}$ & 52,14 & 11,02 & 22,07 \\
$\mathbf{1 9 9 0 - 1 9 9 9}$ & 79,10 & 6,19 & 18,90 \\
$\mathbf{2 0 0 0 - 2 0 1 2}$ & 19,25 & 6,75 & 2,34 \\
\hline
\end{tabular}

Notes: $\pi$ is the annual percentage change of the consumer price index.

Source: Writer's calculation from CBRT dataset.

Table 2 indicating, inflation and narrow money growth rate of some selected developing countries for the time period 1960-1990, gives a chance to make a comparision between developing countries and Turkey. It is seen that in selected developing countries, inflation fluctuate between $437 \%$ and 2, $7 \%$. In these countries generally there is a positive correlation between M1 growth rate and inflation rate. Percentage change of narrow money base and inflation rate moves almost in the same scale in Argentina, Brazil and Uruguay.Table 2 also suggest that if money growth rate is two-digits, inflation is also two digits and vice versa. 
Table 2. Inflation and money growth rate in selected developing countries

\begin{tabular}{lllll}
\hline & Yearly growth rate & $\mathbf{1 9 6 1 - 1 9 7 0}$ & $\mathbf{1 9 7 1 - 1 9 8 0}$ & $\mathbf{1 9 8 1 - 1 9 9 0}$ \\
\hline \multirow{2}{*}{ Argentina } & Inflation Rate & 21,2 & 119,5 & 437,6 \\
& M1 growth rate & 23,2 & 108,6 & 400,4 \\
\multirow{3}{*}{ Chili } & Inflation Rate & 43,5 & 35,3 & 337,1 \\
& M1 growth rate & 48 & 43,5 & 339,8 \\
\multirow{3}{*}{ Israel } & Inflation Rate & 28,9 & 130,3 & 20,3 \\
\multirow{4}{*}{ Mexico } & M1 growth rate & 41 & 147 & 19,5 \\
& Inflation Rate & 5,6 & 41,6 & 91,2 \\
\multirow{2}{*}{ Uruguay } & M1 growth rate & 3,7 & 48,9 & 99,6 \\
& Inflation Rate & 2,7 & 16,5 & 65,1 \\
& M1 growth rate & 12 & 24,4 & 58,4 \\
\hline
\end{tabular}

Source: Carlos A. Vegh. (1992). Stopping High Inflation, IMF Staff Papers, Vol.39, No.3, p.633; Doğru, 2012.

We also make a chronological analysis between inflation (INF), inflation tax (INFTX) and seigniorage (SEIG) revenue of Turkish economy between 1981 and 2011, presented in Figure 1. Definition of Inflation tax is obtained from Bailey (1956), i.e. multiplying annual change in consumer price index (CPI) with the previous year's monetary base $(\triangle C P I * M(-1) / G N P)$, while seigniorage revenue is calculated following Klein and Neumann (1990) and is equal to the change in monetary base $(\Delta M / G N P)$. Both INFTX and SEIG is smoothed by gross national product (GNP), i.e. calculated as a share of GNP. The reference inflation used in this paper is the yearly change in CPI index. All the calculations based on the yearly data from 1981 to 2011, obtained from electronic data service of the Central Bank of the Republic of Turkey. It is seen in figure 1 that Inflation tax and seigniorage revenue fluctuate in the range of 1.55 and 3.95 between 1981 and 1989. Along the whole 1990s and 2000, except during and pre-1994 crisis, both inflation tax and the seigniorage revenue are sticky around 1-1.5\% GNP. Figure 1 also says that during high and volatile inflation periods, due to losses in real money balances, i.e. erosion of real demand for money, taxation base is reduced and thus high and fluctuating inflation does not necessarilyrequire for larger seigniorage revenue (Korap, 2006: 7; Rodrik, 1990: 12).
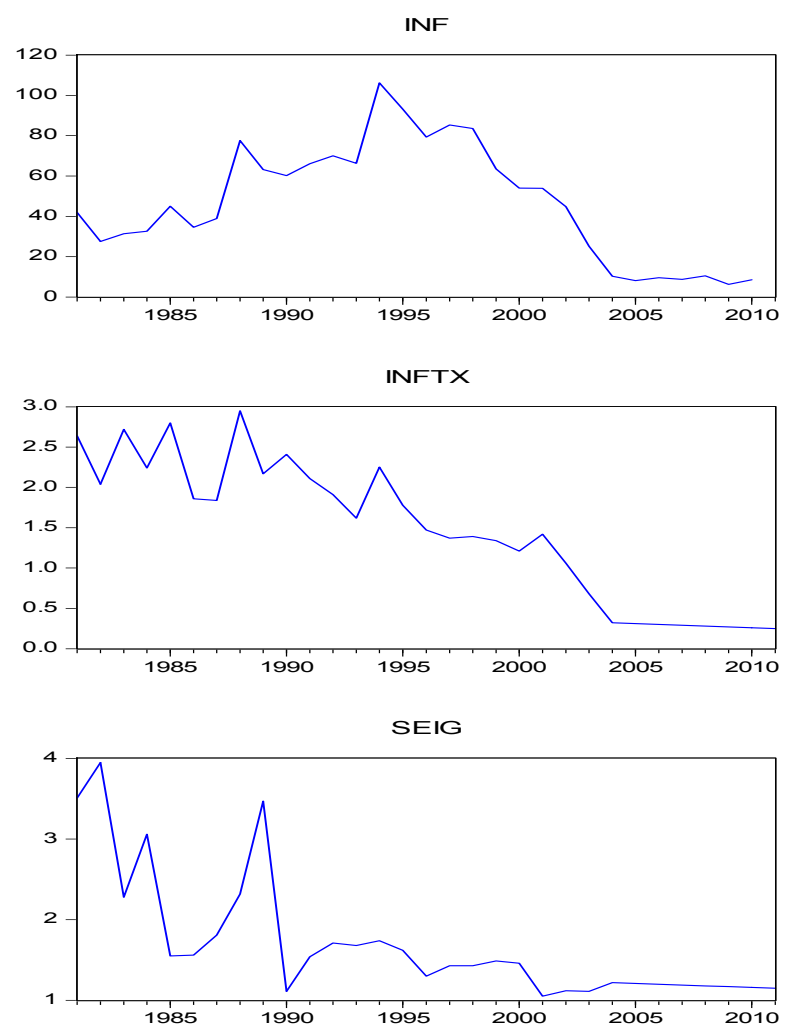

Source: CBRT.

Figure 1. Inflation, inflation tax and seigniorage revenue as share of $\mathrm{G}$ 


\section{Mankiw's (1987) Optimal Seignoriage Model}

Inflationist financing method of budget deficit is denoted by special terms: Inflation tax and seigniorage revenue (Aslan, 2003: 127). Seigniorage is defined as real revenue rose from monopoly power of government on printing money and demonstrated with $\frac{\Delta M}{P}$, rate of change in monetary base to the inflation (Klein and Neumann, 1990: 206). On the other hand inflation tax is a result of inflation and indicates the real capital losses of money holder, and defined as multiplication of inflation rate andreal value of the (outside) quantity of Money: $\pi\left(\frac{M}{P}\right)$ (Phelps, 1973; Bailey, 1956). Here we should also mention "growth seigniorage" which is the result of increasing demand for money in developing countries, having positive real growth rates (Dornbusch and Fischer, 1987: 647).

Following Tobin (1956), Marty (1967) proposed to measure inflation tax with an alternative way by the rate of growth of money supply times real balances (Phelps, 1973: 68; Marty, 1967; 71). In this case real seigniorage revenue is equal to the multiplication of sum of inflation and growth rate and real money balances: $(\pi+$ g) $\left(\frac{M}{P}\right)$ - where g is real growth rate. In his "inflation policy book", Phelps (1972) equals inflation tax to the multiplication of nominal interest rates and real balances, $(\pi+r)\left(\frac{M}{P}\right)$-where $r$ is the real interest rate (Phelps, 1972). This definition expresses that the income obtained by the government is then equivalent to the loss of the interest rate of the private sector (Gürbüz et al., 2009: 56). In this sense, seigniorage is a type of interest-free credit, paid by private sector due to holding liquid balance, transferred to the government (Aslan, 2003: 127-128).

The difference between seignorage and inflation tax is due to the changes in real money demand, arising from the result of changes inthe inflation rate, real income, and interest rates. This difference is usually known as a non-inflationary determinant of seignorage, depending on the increase inthe demand for money that isconsistent withzero inflation rates (Rodrik, 1990: 12).

Given exogenous expenditure and an intertemporal budget constraint, when government expenditure is financed by monetary and fiscal policy, nominal interest rates and inflation move together with tax rates put on output over the time (Mankiw, 1987: 327). According to Mankiw, if fiscal policy dominates monetary policy then government should imply monetary and fiscal policies, targeting minimize social costs depending on tax and seigniorage revenue.

Mankiw'sapproach can be summarizedas follows within the framework ofintertemporal analysis. The optimal intertemporal monetary and fiscal policy of a government should be examined under the following budget constraint in the present value (Mankiw, 1987: 328):

$$
\int_{0}^{\infty} e^{-\rho s} G(t+s) d s+B(t)=\int_{0}^{\infty} e^{-\rho s} T(t+s) d s
$$

Where $G(t)=$ real expenditure at time t, $T(t)=$ real revenue at time t, $B(t)=$ real government debt at time $\mathrm{r}, \rho=$ real discount rate (assumed constant over time). Expenditure is taken to be exogenous, and future expenditure is a random variable. The government takes into consideration two different financing way financing budget deficits to minimize social losses: Tax on output and seigniorage. If level of output and tax rate on output is denoted by $Y(t)$ and $\tau(t)$ respectively, then revenue collected by government is $\tau(t) Y(t)$, and social losses caused bytaxes will be equal to $\mathrm{f}(\tau) \mathrm{Y}$. Here, $f^{\prime}>0$ and $f^{\prime \prime}>0$. Suppose that $M(t), P(t)$ and $k$ in order show exogenous money supply, price level at time $t$ and a constant respectively, then demand for money can be expressed within quantity equation as follows:

$$
\frac{M(t)}{P(t)}=k Y(t)
$$

Suppose that the inflation rate and the growth rate of output are shown by $\pi=\frac{\dot{P}}{P}$ and $g=\frac{\dot{Y}}{Y}$ in order. Then the real seigniorage revenue equals to:

$$
\frac{\dot{M}}{P}=\frac{\dot{M}}{M} \cdot \frac{M}{P}=(\pi+g) k Y
$$

Adding the sum of the receipts from direct taxation and seigniorage, we find a formulation for total government revenue as below:

$$
T=\tau Y+(\pi+g) k Y
$$

Assume that $h(\pi) Y$ indicates social cost of inflation, where $\mathrm{h}^{\prime}>0$ and $\mathrm{h}^{\prime \prime}>0$. Examples to the direct and indirect costs of inflation are menu cost and inefficient functioning of markets respectively. To overcome these costs, the government targets to minimize the expected present value of the social costs under the budget constraint: 


$$
E_{t} \int_{0}^{\infty} e^{-\rho s}[f(\tau)+h(\pi)] Y d s
$$

For this purpose, the government has two choices: Inflation rate $\pi^{1}$ and tax rates. Mankiw then examines the first- order condition of the equation (5) for an optimum as below:

$$
\begin{gathered}
E_{t}\left\{f^{\prime}[\tau(t+s)]\right\}=f^{\prime}[\tau(t)] \\
E_{t}\left\{h^{\prime}[\pi(t+s)]\right\}=h^{\prime}[\pi(t)] \\
h^{\prime}[\pi(t)]=k f^{\prime}[\tau(t)]
\end{gathered}
$$

Under budget constraint the optimal monetary and fiscal policy satisfies these three equations.

The intertemporal first-order conditions (6) and (7) in order equates marginal social cost of taxation today and in the future, and the marginal social cost of inflation today and in the future. While, the static first-order condition (8) equates the marginal social costs of raising revenues through direct taxation and through seigniorage. According to first-order condition of equation (8), an increase in the government revenue requirement increases the use of both direct taxation and seigniorage. This usage leads a parallel movement between level of taxation, inflation and nominal interest rates (Mankiw, 1987: 329-331). Mankiwtest his optimal seigniorage theory for USA for a long time period covering 1952-1985. Findings are in the direction that there is a positive relationship between nominal interest rates and level of direct taxation. He has also obtained a log-run relationship between inflation rate and level of direct taxation.

\section{Empirical Analysis}

In this part, optimal seigniorage theory is tested for Turkish Economy with yearly data between 1980-2012. The fundamental property of the optimal seigniorage theory is that inflation rate and nominal interest rates are determined by revenue requirement of the government. If we could collect reliable estimates for marginal social cost of inflation, marginal social cost of direct taxation and interest elasticity of money demand, then equation (8) could be estimated to find out relationship between level of direct taxation, inflation and nominal interest rates at any point in time. Because we do not know these social costs, we prefer linear approximation to equation (8) for Turkish economy, as Mankiw did for USA, with time series data (Mankiw, 1987: 332).

The goal of this study is to test the implication of optimal seigniorage theory that in the long run higher tax rates are associated with higher inflation rates and higher nominal interest rates. Namely, acointegration relationship between nominal interest rates, inflation and taxes is examined. We will decide whether there is a long-run equilibrium path for these variables. If they move together there should be an equilibriumpoint which nominal interest rates, inflation and taxes are converging to.

Data used in this paper obtained from statistics of ministry of finance, data delivery system of the undersecretaries of treasury and Central Bank of the Republic of Turkey. Definitions and some basic descriptive statistics of the variables we employed in the model are presented in table 3 with in level and in first differences. The choice of variables used in the model is based on previous studies in the related empirical literature. Table 3 indicates that maximum volatility happens in INT and INF variables, corresponding in order to the inflation and compound interest rates during the time period considered. The mean of first differences given in table 3 are very near but not equal to zero. Hence, these findings could be accepted as the evidence of linear deterministic trend in levels of series (Güloğlu and Ivrendi, 2010).

Table 3. Descriptive statistics and definition of series in level

\begin{tabular}{lllllll}
\hline Variables & Def. & Mean & S. Dev & Min. Val. & Max. Val. & Obs. \\
\hline INF & Percentage change of CPI & 44.3 & 29.3 & 5.5 & 106.2 & 32 \\
TAX & Ratio of total tax revenue to the GNP & 0.16 & 0.05 & 0.10 & 0.24 & 32 \\
INT & Compound interest ratesheld in nominal interest rates & 50.8 & 59.9 & 6.24 & 342.2 & 32 \\
dINF & First difference of INF & -1.17 & 13.48 & -19.97 & 39.87 & 31 \\
dTAX & First difference of TAX & 0.002 & 0.01 & -0.02 & 0.04 & 31 \\
dINT & First difference of INT & -0.40 & 68.72 & -265.86 & 258.17 & 31 \\
\hline
\end{tabular}

Source: CBRT.

In the next section, we will firstly investigate stationarity and level of integration of time series we employ in the model. The determination of the degree of integration of series and the choice of appropriate cointegration analysis I(1) or I(2) is important to make appropriate econometric analysis (Güloğlu and İvrendi, 2010: 9). There are also some potential problems of using non-stationary data. Because non-stationary time series can cause 
spurious (non-sense) regression results, as noted by Granger and Newbold (1974). Assume that we have a single equation as follow:

$$
Y_{t}=\beta_{1}+\beta_{2} X_{t}+u_{t}
$$

Where $Y_{t} \sim \mathrm{I}(1)$ and $\mathrm{X}_{\mathrm{t}} \sim \mathrm{I}(1)$. If unit root tests on residuals indicates that $\mathrm{u}_{\mathrm{t}} \mathrm{is}$ stationary, then it is concluded thatsome linear combination of series $Y_{t}$ and $X_{t}$ is stationary, although $Y_{t}$ and $X_{t}$ are individually non-stationary. In other words, linear combinations delete stochastic trend in series $X_{t}$ and $Y_{t}$. In this case, established regression line is significant and $X_{t}$ and $Y_{t}$ is cointegrated. They move together in long run, and converge to an equilibrium path over the time (Engle and Granger, 1987: 251-276).

\subsection{Unit Root Tests}

Augmented Dickey Fuller (ADF) and Kwiatkowski-Phillips-Schmidt-Shin (KPSS) unit root tests are employed to determine whether the variables are stationary. The unit root tests also turn out to be important in the determination of the degree of integration of series and the choice of appropriate cointegration analysis I(1) or I(2). ADF and KPSS unit root tests results for first differences of the series are presented in table 4 and table 5 . The tables suggest that all of the series are I (1). Also this result can be seen from the graphs of series in first difference illustrated in figure 1 to figure 3 . The graphical analysis of the differenced series indicatesthat the series are stationary with mean near zero.

Table 4. ADF test results

\begin{tabular}{llll}
\hline & $\tau$ (No intercept no trend) & $\tau_{\mu}$ (Intercept) & $\tau_{\mathrm{t}}$ (Intercept and Trend) \\
\hline INF & -0.891 & -0.897 & -1.486 \\
TAX & -0.879 & -0.403 & -1.664 \\
INT & -2.594 & $-3.68^{*}$ & $-3.69^{*}$ \\
dINF & $-5.953^{* * *}$ & $-5.855^{* * *}$ & $-6.164^{* * *}$ \\
dTAX & $-5.489^{* * *}$ & $-5.768^{* * *}$ & $-5.616^{* * *}$ \\
dINT & $-8.923^{* * *}$ & $-8.770^{* * *}$ & $-8.698^{* * *}$ \\
\hline
\end{tabular}

Notes: Lag lengths are selected automatically according to Akaike Info Criterion. The critical values of test statistics $\left(\tau, \tau_{\mu}, \tau_{\mathrm{t}}\right)$ are tabulated in Fuller (1976) and MacKinnon (1996). *: Test statistics are significant at $10 \%$ level of significance. **: Test statistics are significant at 5\% level of significance. ${ }^{* *}$ : Test statistics are significant at $1 \%$ level of significance.

Table 5. KPSS unit roots test results

\begin{tabular}{lll}
\hline & $\tau_{\mu}($ Intercept $)$ & $\tau_{\mathrm{t}}$ (Intercept and Trend $)$ \\
\hline INF & 0.208 & 0.207 \\
TAX & 0.540 & 0.208 \\
INT & 0.354 & 0.366 \\
dINF & $0.244^{* * *}$ & $0.106^{* * *}$ \\
dTAX & $0.102^{* * *}$ & $0.148^{* *}$ \\
dINT & $0.172^{*}$ & $0.180^{*}$ \\
\hline
\end{tabular}

Notes: *: The null hypothesis of stationarity is not rejected at $10 \%$ level of significance. $* *$ : The null hypothesis of stationarity is not rejected at $5 \%$ level of significance. ***: The null hypothesis of stationarity is not rejected at $1 \%$ level of significance. Critical values are taken from Kwiatkowski-Phillips-Schmidt-Shin (1992) Table 1.

As a result, we use I(1) of the variables to determine the number of cointegration vector by using Johansen analysis.

\subsection{Cointegration Analysis}

In this part we are examining whether the variables are cointegrated with each other. We know from Engle Granger (1987) that statitonary time series could make a linear combination converging to a long run equilibrium point over time. If one or more linear combination of individually non-stationary series is stationary then these series may be cointegrated. This means that these series cannot move too far away from each other (Dickey, Jansen and Thorton, 1991:58). We conclude from unit root tests that a VAR- based cointegration relationship developed by Johansen (1995) should be estimated in order to capturethe long termrelationships between variables. For this purpose, we estimate a k-lag Vector Error Correction Model by Johansen Method. But firstly, we determine lag length of unrestricted VAR model considering six different lag selection criterions including likelihood Ratio (LR), Final Prediction Error Criterion (FPE), Akaike information criterion (AIC), Schwarz 
information criterion (SC) and Hannan-Quinninformation criterion (HQ). VAR lag order selection criteria results are shown in table 6. The maximum lag number selected is 6 .Besides endogenous variables we also add three dummy variables (D94, D01 and D08) in VAR model, to take into account the unpredicted shock effects of three economic crises: Two domestic and one global financial crisis occurred in 1994, 2001 and 2008 respectively. The dummy variables D94, D01 and D08 are unity for year 1994, 2001 and 2008 and zero otherwise. According to table 6, all the lag selection criterions suggest 2 lag orders.

Table 6. VAR lag order selection criteria

\begin{tabular}{llllll}
\hline Lag & LR & FPE & AIC & SC & HQ \\
\hline 0 & NA & 214.1282 & 13.87282 & 14.45348 & 14.04003 \\
1 & 100.2688 & 2.259201 & 9.287821 & 10.30398 & 9.580437 \\
2 & $26.26588^{*}$ & $1.777092^{*}$ & $1.963511^{*}$ & $5.41516^{*}$ & 2.381534 \\
3 & 9.361682 & 2.050114 & 8.935689 & 10.82283 & 9.479119 \\
4 & 9.474528 & 2.181165 & 8.680544 & 11.00318 & 9.349381 \\
5 & 7.084435 & 2.842831 & 8.360790 & 11.11892 & 9.155033 \\
6 & 21.30849 & $2.01561^{*}$ & $8.975976^{*}$ & 10.169605 & $9.895626^{*}$ \\
\hline
\end{tabular}

Notes: * indicates lag order selected by the criterion. LR: sequential modified LR test statistic (each test at $5 \%$ level). FPE: Final prediction error. AIC: Akaike information criterion. SC: Schwarz information criterion. HQ: Hannan-Quinn information criterion.

In order to determine the cointegration rank, we employ Johansen Test method. There are two test statistics for the number of cointegrating vectors: The trace and maximum eigenvalue statistics. In the trace test, the null hypothesis is that the number of cointegrating vectors is less than or equal to $r$, where $r$ is 0,1 or 2 . In each case the alternative hypothesis is tested against general alternative. In the case of the maximum eigenvalue test, the null hypothesis $r=0$ is tested against the alternative that $r=1$, and null hypothesis $r=1$ is tested against the alternative $\mathrm{r}=2$, etc. The critical values for these tests are obtained from Johansen and Juselius (1990). Table 7 presents the results of Johansen Cointegration Test using the maximum eigenvalue and the trace tests. We cannot reject the hypothesis that $\mathrm{r} \leq 2$, while the hypothesis $\mathrm{r}=0$ and $\mathrm{r}=1$ can be rejected for the trace test indicating that there is one cointegrating vector.For the maximum eigenvalue test, the hypothesis $r=0$ is rejected in favor of the $\mathrm{r}=1$. Hence, both trace and max-eigen statistics suggest that there exists a unique cointegration relation $(\mathrm{r}=1)$ among three variables. Consequently, these two tests indicate that inflation is cointegrated with taxes and nominal interest rates.

Table 7. Johansen cointegration test and cointegrating vectors for INT

Test statistics

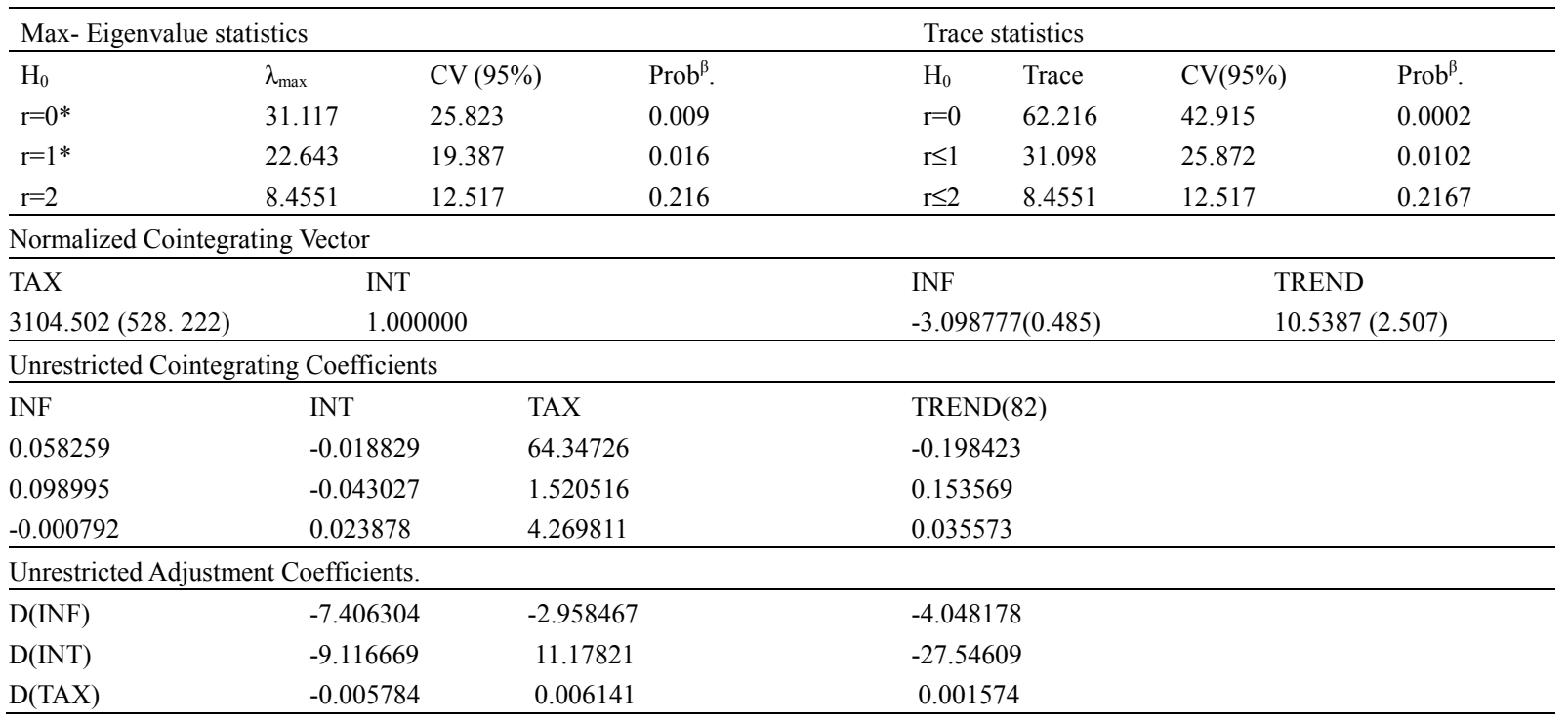

Notes: CV denotes critical values, Critical values are tabulated from Johansen and Juselius (1990). * Indicates statistical significance at the 5 percent level. $\beta$ shows MacKinnon-Haug-Michelis (1999) p-values. 
Table 7 reports one cointegrating vector linking inflation, tax and nominal interest rates. But a cointegrating vector barely represents a long run relationship between endogenous variables. Because they are interpreted that there is one linear combination for which the variance is bounded (Dickey, Jansen and Thorton, 1991: 76). Structural short and long-run relationships are indicated in VECM estimation. A VECM model with our variables is simply stated as follow:

$$
d\left(I N T_{t}\right)=\beta_{0}+\beta_{1} * d\left(I N F_{t}\right)+\beta_{2} * d\left(T A X_{t}\right)+\beta_{3} * E C T(-1)+\varepsilon_{t}
$$

Where; INT, INF and TAX are at the first differenced variables. $\beta_{0}$ is intercept, $\beta_{1}$ and $\beta_{2}$ are short run coefficient and $\operatorname{ECT}(-1)$ is the one period lag residual of below model:

$$
I N T_{t}=\theta_{0}+\theta_{1} * I N F_{t}+\theta_{2} * T A X_{t}+\vartheta_{t}
$$

$\operatorname{ECT}(-1)$ shows the adaptation rate to the long run equilibrium, and is also known as equilibrium error term of one period lag. ECT (-1) is an error correction term and leads variables INT, INF and TAX of the system to converge or to back to the long run equilibrium point. It corrects disequilibrium. Therefore, the sign of $\beta_{3}$ should be negative. The significant and negative $\beta_{3}$ coefficient shows what rate it corrects the previous period disequilibrium of the system. Hence, it means that there exists a long run equilibrium relationship among variables INT, TAX and INF stated in model 11.

VECM estimation result with two lagged is reported in Table 8. The coefficient of error correction term (ECT $(-1)$ ) of the model 1 has been -0.31 meaning that system corrects its previous period disequilibrium at a speed of approximately 31 percent yearly. In other saying, almost $31 \%$ of deviation from long run equilibrium is smoothed in one year.Moreover the sign of ECT(-1) coefficient, significant and negative, as it is expected, indicates that there existed a long run causality from INF and TAX to INT. Error correction term of the model 2 and 3 is insignificant. This result indicates that in long run tax revenue and nominal interest rates cause inflation.

According to estimation result of cointegration equation (long-run relationship) on the top of table 8 there is a strong and significant long run relationship between nominal interest rates and inflation. It implies that an increase in inflation is associated with a 2.51 percentage increase in the nominal interest rates. Direction of the relationship is positive (In a cointegration model like the $a x+b y+c z=0$, signs are reversed to find relationship). The relationship between direct taxation and nominal interest rate is also significant but the coefficient on TAX appears very large. It implies that an increase in government revenue of 1 percent of GNP is associated with a 42.61 percentage point increase in the nominal interest rate.

These results supports the optimal seigniorage theory suggesting that in the long run tax rates, inflation rates and nominal interest rates move together. Our findings are also in line with study of Mankiw (1987) on American Economy. However, these estimation results are not consistent with the empirical study of Aslan (2003) testing optimal seignoraige theory for Turkish economy. The linear trend variable is significant and negatively related to the inflation as it is predicted from unit root tests and figure 1 to 3 .

To check short run causality we use Wald test. If the coefficient of $\mathrm{D}(\operatorname{INF}(-1)), \mathrm{D}(\operatorname{INF}(-2)), \mathrm{D}(\mathrm{TAX}(-1))$ and $\mathrm{D}(\mathrm{TAX}(-2))$ jointly influence the INT variable then we conclude that there is the short run causality from INF and TAX to INT. Table 9 presents Wald test result. According to Chi-square statistics, we cannot reject null hypothesis suggesting that all the coefficients are equal to zero. It means that all the lags of TAX and INF jointly cannot cause INT. There is no short run causality coming from INF and TAX to INT. 
Table 8. VECM estimation results

\begin{tabular}{|c|c|c|c|}
\hline \multicolumn{4}{|c|}{ Cointegration eq: INT(-1) $-2.51 * \operatorname{INF}(-1)-42.6 * \mathrm{TAX}(-)+2.14 * \mathrm{TREND}+28.90=$} \\
\hline & Model1 & Model2 & Model3 \\
\hline Error Correction: & $\mathrm{D}(\mathrm{INT})$ & $\mathrm{D}(\mathrm{TAX})$ & $\mathrm{D}(\mathrm{INF})$ \\
\hline \multirow[t]{3}{*}{$\mathrm{ECT}(-1)$} & -0.316337 & $-4.32 \mathrm{E}-05$ & -0.013748 \\
\hline & $(0.55628)$ & $(0.00011)$ & $(0.10235)$ \\
\hline & {$[-3.15521]$} & {$[-0.39565]$} & [ 1.06555$]$ \\
\hline \multirow[t]{3}{*}{$\mathrm{D}(\mathrm{INF}(-1))$} & -0.499130 & $4.03 \mathrm{E}-05$ & -0.199339 \\
\hline & $(0.46037)$ & $(9.0 \mathrm{E}-05)$ & $(0.08470)$ \\
\hline & {$[-1.08420]$} & {$[0.44621]$} & {$[-2.35345]$} \\
\hline \multirow[t]{3}{*}{$\mathrm{D}(\mathrm{INF}(-2))$} & -0.282119 & $3.71 \mathrm{E}-06$ & -0.103646 \\
\hline & $(0.29943)$ & (5.9E-05) & $(0.05509)$ \\
\hline & {$[-0.94219]$} & {$[0.06312]$} & {$[-1.88138]$} \\
\hline \multirow[t]{3}{*}{ D(INT(-1)) } & 701.4302 & 0.137932 & 357.7651 \\
\hline & (1206.70) & $(0.23691)$ & $(222.015)$ \\
\hline & [ 0.58128] & {$[0.58221]$} & [ 1.61145$]$ \\
\hline \multirow[t]{3}{*}{ D(INT(-2)) } & -355.1551 & 0.096274 & 169.3505 \\
\hline & $(1077.27)$ & $(0.21150)$ & $(198.201)$ \\
\hline & {$[-0.32968]$} & {$[0.45520]$} & [ 0.85444$]$ \\
\hline \multirow[t]{3}{*}{$\mathrm{D}(\mathrm{TAX}(-1))$} & -0.352392 & -0.000449 & 0.041410 \\
\hline & $(1.26205)$ & $(0.00025)$ & $(0.23220)$ \\
\hline & {$[-0.27922]$} & [-1.81092] & [ 0.17834$]$ \\
\hline \multirow[t]{3}{*}{$\mathrm{D}(\mathrm{TAX}(-2))$} & 0.606579 & $5.32 \mathrm{E}-05$ & -0.097041 \\
\hline & $(1.23043)$ & $(0.00024)$ & $(0.22638)$ \\
\hline & [ 0.49298] & {$[0.22041]$} & {$[-0.42866]$} \\
\hline \multirow[t]{3}{*}{$\mathrm{C}$} & -1.946451 & 0.001924 & -3.000102 \\
\hline & (14.1319) & $(0.00277)$ & $(2.60005)$ \\
\hline & {$[-0.13773]$} & [ 0.69345$]$ & {$[-1.15386]$} \\
\hline \multirow[t]{3}{*}{ D94 } & 44.97880 & 275.8908 & 0.003295 \\
\hline & (12.8101) & (11.4141) & $(0.01479)$ \\
\hline & [ 3.51120$]$ & [ 24.1710] & [ 0.22272$]$ \\
\hline \multirow[t]{3}{*}{ D01 } & 9.797895 & 34.76976 & -0.002383 \\
\hline & $(16.5680)$ & $(14.7625)$ & $(0.01913)$ \\
\hline & [ 0.59138] & [ 2.35528] & {$[-0.12452]$} \\
\hline \multirow[t]{3}{*}{ D08 } & -4.972880 & -3.792858 & 0.006494 \\
\hline & $(12.5502)$ & (11.1826) & $(0.01449)$ \\
\hline & {$[-0.39624]$} & {$[-0.33918]$} & [ 0.44804$]$ \\
\hline R-squared & 0.313653 & 0.238697 & 0.372873 \\
\hline Adj. R-squared & 0.084871 & -0.015071 & 0.163830 \\
\hline Sum sq. resids & 97246.88 & 0.003748 & 3291.845 \\
\hline S.E. equation & 68.05001 & 0.013360 & 12.52017 \\
\hline F-statistic & 1.370968 & 0.940612 & 1.783718 \\
\hline
\end{tabular}

Notes: Standard erroros and t- values are given in () and [] respectively.

Table 9. Diagnostic test: wald test result

\begin{tabular}{llll}
\hline Test Statistic & Value & df & Probability \\
\hline F-statistic & 0.182501 & $(4,21)$ & 0.9449 \\
Chi-square & 0.730003 & 4 & 0.9476 \\
\hline
\end{tabular}

Our model also has no heteroscedasticity and serial correlation problems shown at Appendix.

\section{Conclusion}

In this study, we tested Mankiw's (1987) optimalseignioragetheory for Turkish economyusing yearly time series dataset for the period 1980-2011. This theory suggests that in the long run higher tax rates are associated with higher inflation rates and higher nominal interest rates. We use cointegration and vector error correction methods 
(VECM) to find long run and short run relationship between variables.

Econometric results of the study supports the optimal seigniorage theory suggesting in the long run higher tax rates are associated with higher inflation rates and higher nominal interest rates in Turkey. There is only one long run causality from inflation and tax revenue to nominal interest rates. Moreover, $31 \%$ of any deviation from long run equilibrium is smoothed in one year or in three year deviations converges to equilibrium point. Model suggests that one percent increase in inflation and tax revenue per GNP is associated with 2.5 and 42.6 percent increase in the nominal interest rates respectively.

Our findings are in line with study of Mankiw (1987) on American economy. However, these estimation results are not consistent with the empirical study of Aslan (2003) testing optimal seignoraige theory for Turkish economy.

VEC model also suggest that there is no short run causality from inflation and tax revenue to nominal interest rates.

\section{References}

Aslan, M. H. (2003). Türkiye'de Optimal SenyorajTeorisive Kamu Finansmanı Üzerine Ampirik Bulgular. AfyonKocatepe Üniversitesi İBF Dergisi, C.V, S.l, 1123-144.

Bailey, M. J. (1956). Welfare cost of inflationary finance. Journal of Political Economy, 64, 93-110. http://dx.doi.org/10.1086/257766

Begg, D., Fischer, S., \& Dornbusch, R. (1994). Economics (4th ed.). McGraw-Hill Book Company.

Cagan, P. (1956). The Monetary Dynamics of Hyperinflation. In Friedman, M. (Ed.), Studies in the Quantity Theory of Money (pp. 25-117). Chicago: The University of Chicago Press.

Cooley, T. F., \& Hansen, G. D. (1989). The Inflation Tax in a Real Business Cycle Model. The American Economic Review, 79(4), 733-74.

Dickey, D. A., Jansen, D. W., \& Thornton, D. L. (1991). A Primer on Cointegration with an Application to Money and Income. Federal Reserve Bank of St. Louis Review, 58-78.

Dogru, B. (2011). Para Politikası Ara Rejim Hedeflemesine Göre Türkiye Cumhuriyet Merkez Bankası Performans Kriterlerini Etkileyen Faktörler: 1990-2011. İstanbul Üniversitesi Sosyal Bilimler Enstitüsü Basılmamış DoktoraTezi.

Dombusch, R., \& Fischer, S. (1987). Macroeconomics (4th ed.). NewYork: McGraw-Hil.

Engle, R. F., \& Granger, C. W. J. (1987). Cointegration and Error Correction: Representation, Estimation, and Testing. Econometrica, 55, 251-276. http://dx.doi.org/10.2307/1913236

Foote, C. (2010). Money and Inflation. Lecture notes, Harvard University Department of Economics.

Friedman, M. (1971). Government Revenue from Inflation. The Journal of Political Economy, 79(4), 846-856. http://dx.doi.org/10.1086/259791

Fuller, W. A. (1976). Introduction to the Statistical Time Series. New York: John Wiley.

Granger, C. W. J., \& Newbold, P. (1974). Spurious Regressions in Economics. Journal of Econometrics, 2(2), 111-120. http://dx.doi.org/10.1016/0304-4076(74)90034-7

Güloğlu, B., \& İvrendi, M. (2010). The Effects of Monetary Policy Shocks on Exchange Rate: A Structural VECM With Long-Run Restrictions.

Gürbüz, B., et al. (2010). Seigniorage and Public Deficit: A Test of Comparison between Turkey and Tunisia. International Journal of Business and Management, 4(9), 55-71.

Klein, M., \& Neumann, M. J. M. (1990). Seigniorage: What is It -Who Gets It? Welswirtschaftliches Archiv, 126, Korap, L. (2006). Seigniorage Revenue AndTurkish economy. MPRA Paper, No. 20106.

Kwiatkowski et al. (1992). Testing The Null Hypothesis of Stationarity Against The alternative of A Unit Root. Journal Of Econometrics, 54, 159-178. http://dx.doi.org/10.1016/0304-4076(92)90104-Y

Mackinnon, J. G. (1996). Numerical Distribution Functions for Unit Root andCointegration Tests. Journal of Applied Econometrics, 11, 601-618. http://dx.doi.org/10.1002/(SICI)1099-1255(199611)11:6<601::AID-JAE417>3.0.CO;2-T

Mankiw, N. G. (1987). The Optimal Collection of Seigniorage Theory and Evidence. Journal of Monetary 
Economics, 20, 327-341. http://dx.doi.org/10.1016/0304-3932(87)90019-5

Marty, A. L. (1967). Growth and the Welfare Cost of Inflationary Finance. Journal of Political Economy, 75. http://dx.doi.org/10.1086/259239

Osterwald-Lenum, M. (1992). A Note with Quantiles of the Asymptotic Distribution of the Maximum Likelihood Cointegration Rank Test Statistics. Oxford Bulletin of Economics and Statistics, 54, 461-472. http://dx.doi.org/10.1111/j.1468-0084.1992.tb00013.x

Phelps, E. S. (1972). Inflation Policy and Unemployment Theory. New York: W. W. Norton and Co.

Phelps, E. S. (1973). Inflation in the Theory of Public Finance. Swedish Journal of Economics, 75(1), 67-82. http://dx.doi.org/10.2307/3439275

Rodrik, D. (1990). Premature Liberalization, Incomplete Stabilization: The Ozal Decade in Turkey. NBER Working Paper, No. 3300.

Samimi, A., Nademi, Y., \& Ghaderi, S. (2012). Inflation and Inflation Tax in Developing Countries; A Panel Threshold Approach. International Journal of Academic Research in Economics and Management Sciences, $1(1)$.

Vegh, C. A. (1992). Stopping High Inflation. IMF Staff Papers, 39(3), 625-695. http://dx.doi.org/10.2307/3867476

\section{Appendix}
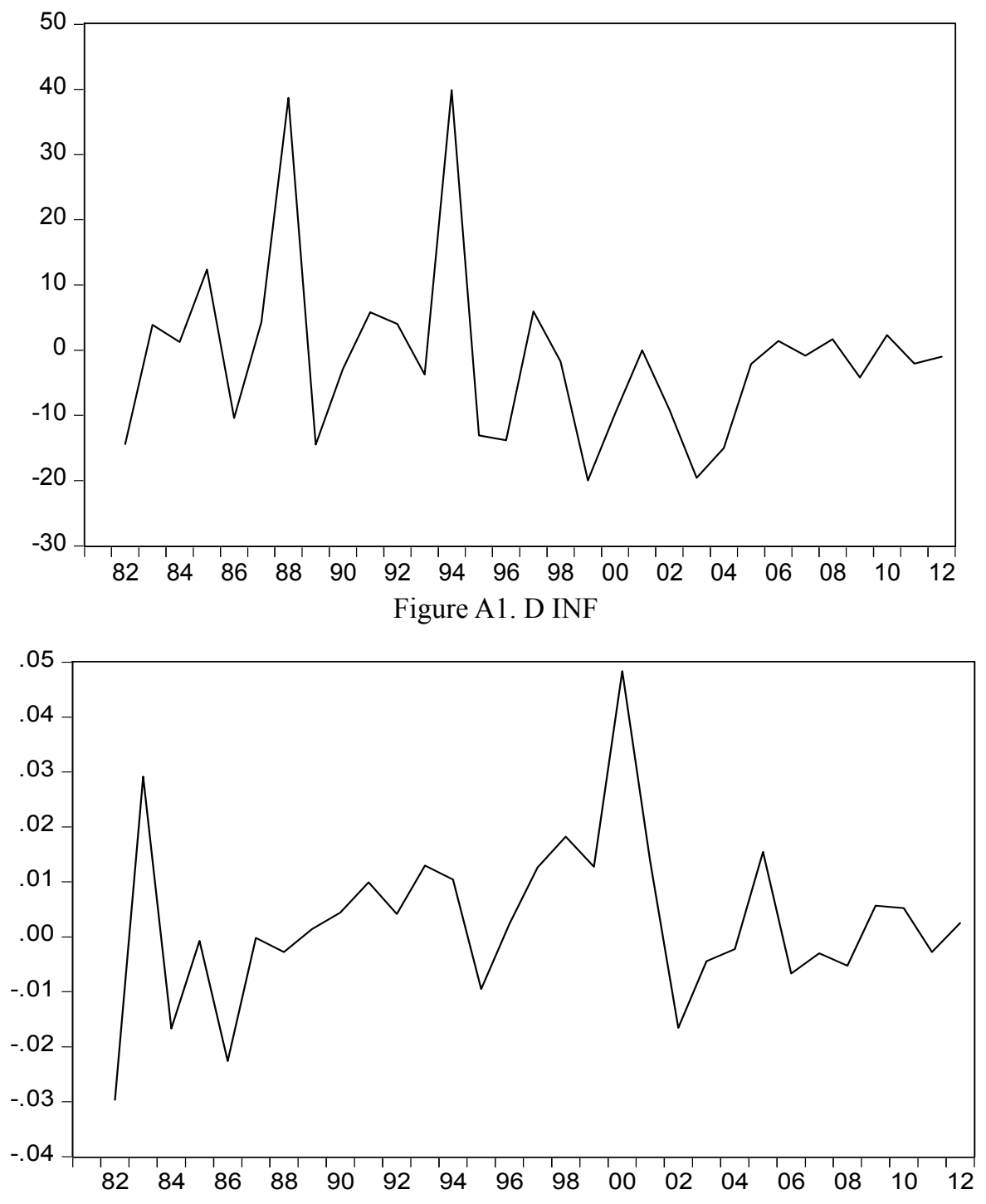

Figure A2. D TAX 


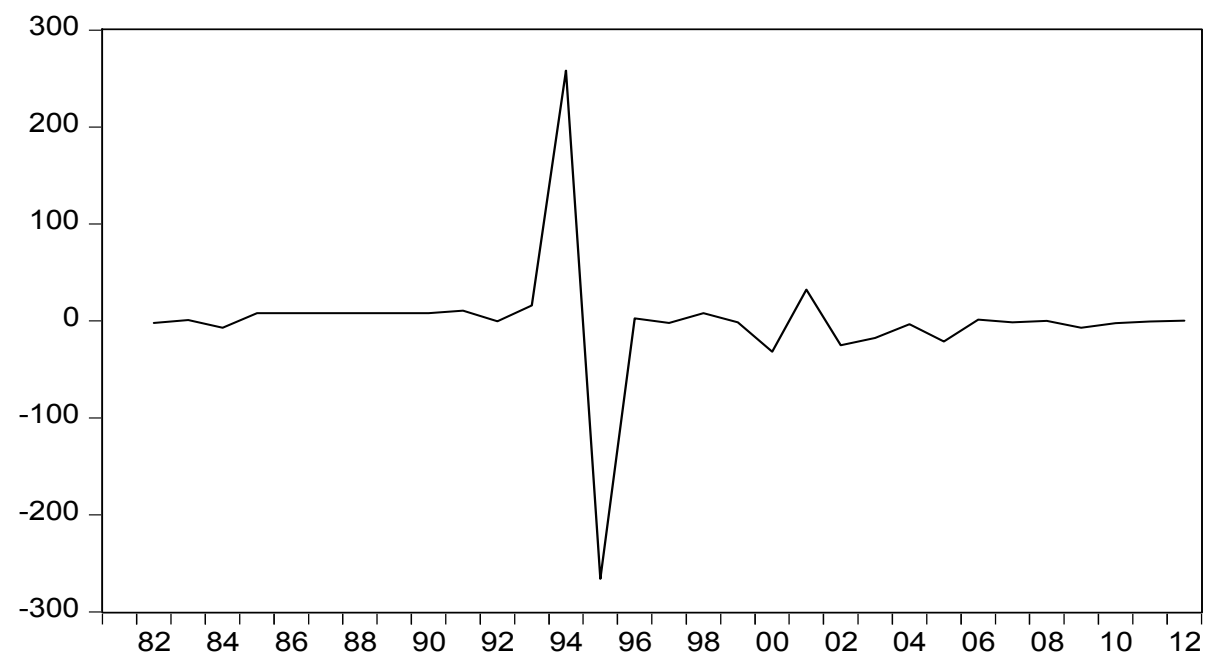

Figure A3. D INT

Graphes of Variables in First Difference

\section{Heteroskedasticity Test: $\mathrm{ARCH}$}

\begin{tabular}{llll}
\hline \hline F-statistic & 0.169003 & Prob. F(2,24) & 0.8455 \\
Obs*R-squared & 0.374975 & Prob. Chi-Square(2) & 0.8290
\end{tabular}

Null hypothesis: There is no ARCH effect

\section{Breusch-Godfrey Serial Correlation LM Test:}

\begin{tabular}{llll}
\hline \hline F-statistic & 0.793290 & Prob. F(2,19) & 0.4668 \\
Obs*R-squared & 2.234990 & Prob. Chi-Square(2) & 0.3271
\end{tabular}

Null hypothesis: There is no serial correlation

Notes: ${ }^{1}$ Here inflation is used in the sense of moneystock, but givenoutput, this is equivalenttochoosingthe rate of inflation (Mankiw, 1987: $330)$. 